\title{
THE LONG ROOTS OF THE PRESENT CRISIS: KEYNESIANS, AUSTERIANS, AND MARX'S LAW
}

\author{
Guglielmo Carchedi and Michael Roberts
}

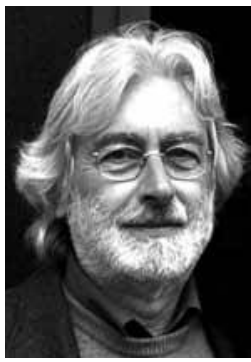

Guglielmo Carchedi, Emeritus, University of Amsterdam. Adjunct Professor, York University, Toronto. His latest book is Behind the Crisis (Brill, 2011).Email: carchedi38@gmail.com

Michael Roberts, independent researcher, currently working in the City of London as an economist. BA in Economics, University of Sussex. Author of The Great Recession: Profit Cycles, Economic Crisis-A Marxist View (Lulu.com, 2009). Email: bobmckee99@yahoo.com

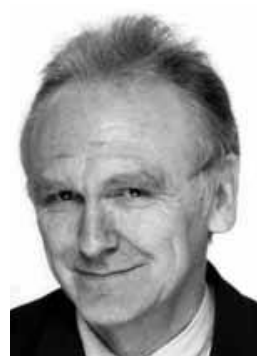

\begin{abstract}
The ultimate cause of crises in capitalism is lack of profitability. The Keynesian and Austerians (the supporters of austerity measures), deny this. So their solutions to crises do not work. Keynesian state-induced stimulus programs (redistributive, monetary, and fiscal) cannot overcome the underlying tendency for profitability to fall. The same holds for the policies of "austerity," which are designed to reduce debt and raise profitability. These conclusions are particularly relevant for the weaker Eurozone economies in the midst of the euro crisis. In a case study of Argentina, we argue that it was not competitive devaluation that restored growth after the 2001 crisis, but default on state debt caused by the previous destruction of productive capital.
\end{abstract}

Key words: long roots; Keynesians; Austerians; Marx's Law

\section{Profit Calls the Tune}

Capitalism does not develop in a straight line upwards. Its movement is subject to recurrent cycles of "booms and slumps" that destroy and waste much of the value previously created. For example, the 1880 s and 1890 s saw a massive destruction of US value and wealth; and the Great Depression of the 1930s also. Now we have suffered the first Great Recession and are in the Long Depression of the $21 \mathrm{st}$ century. We hold that the key to understanding the sequence of booms and busts is the movement of the profit rate. ${ }^{1}$

Individual capitalist businesses compete with each other to sustain and increase not only the mass of profits but also their profits relative to the capital invested. To do so, they increasingly use new technology to boost the productivity of labor. But 
this is capitalism's Achilles' heel. The accumulated cost of investing in new plant, equipment etc. inexorably rises compared to the size and cost of the labor force. As only labor can create value (a point to be empirically substantiated below), the value and surplus value generated by the capitals investing in new methods of production begins to fall. On the other hand, these capitals are more efficient and produce a greater output. By selling it at the same price as the lower output of the technologically backwards capitalists, they appropriate a share of the surplus value produced by the latter. Their rate of profit rises but that of the technologically less efficient capitals and of the economy as a whole falls. ${ }^{2}$ If other capitalists modernize as well, profitability falls consistently. Eventually it will cause a fall in the mass of profit. Then capitalists stop investing and "go on strike." A crisis ensues.

Capitalists try to avoid the crisis in various ways: by trying to exploit workers more; by looking for yet more efficient technologies; and by speculating in unproductive areas of the economy, e.g. the stock market and banking and finance, where they gamble for gain. National capitalist economies look for new sources of labor supply to exploit abroad and new foreign markets from which to appropriate (surplus) value. These are some of the counteracting factors to the main law of profitability, the "law as such." But these counteracting factors can only work for a while. Eventually, the law of falling profitability will operate.

Empirical evidence confirms this. We shall focus on the US since the Second World War. ${ }^{3}$ Figure 1 shows that the rate of profit has been falling since the mid-1950s and is well below where it was in $1947 .{ }^{4}$ There has been a secular decline. But the rate of profit has not moved in a straight line. After the war, it was high but decreasing in the so-called Golden Age from 1948 to 1965. This was also the fastest period of economic growth in American history. Profitability kept falling also from 1965 to 1982. GDP growth was much slower and American capitalism (like elsewhere) suffered severe slumps in 1974-75 and 1980-82.

Then, as Figure 2 shows, in the era of what is called "neo-liberalism" from 1982 to 1997, profitability rose. Capitalism managed to get the counteracting factors to falling profitability into play, i.e. greater exploitation of the American workforce (falling wage share); wider exploitation of the labor force elsewhere (globalization), and speculation in unproductive sectors (particularly, real estate and finance capital). Between 1982 and 1997, the rate of profit rose 19 percent, as the rate of surplus value rose nearly 24 percent and the organic composition of capital rose just 6 percent. ${ }^{5}$

This "neo-liberal period" had less severe slumps, although economic growth was still slower than in the Golden Age, because profitability was still below the period of the Golden Age, particularly in the productive sectors of the US economy. ${ }^{6}$ Much of the profit was diverted away from real investment and into the financial sector. Profitability peaked in 1997 and began to decline. Between 1997 and 2008, the rate of profit dropped 6 percent, the rate of surplus value fell 5 percent, while 


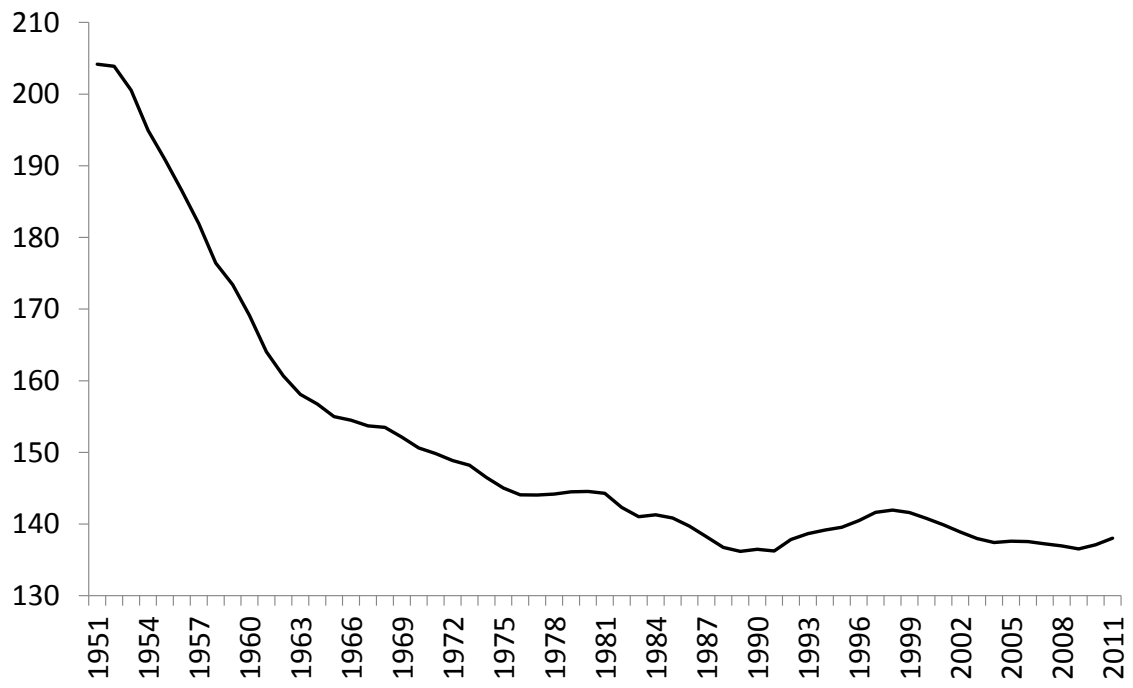

Figure 1 US average rate of profit, ten-year rolling annual average, 1951-2011 (indexed, $1947=100$ )

Source: See Appendix.

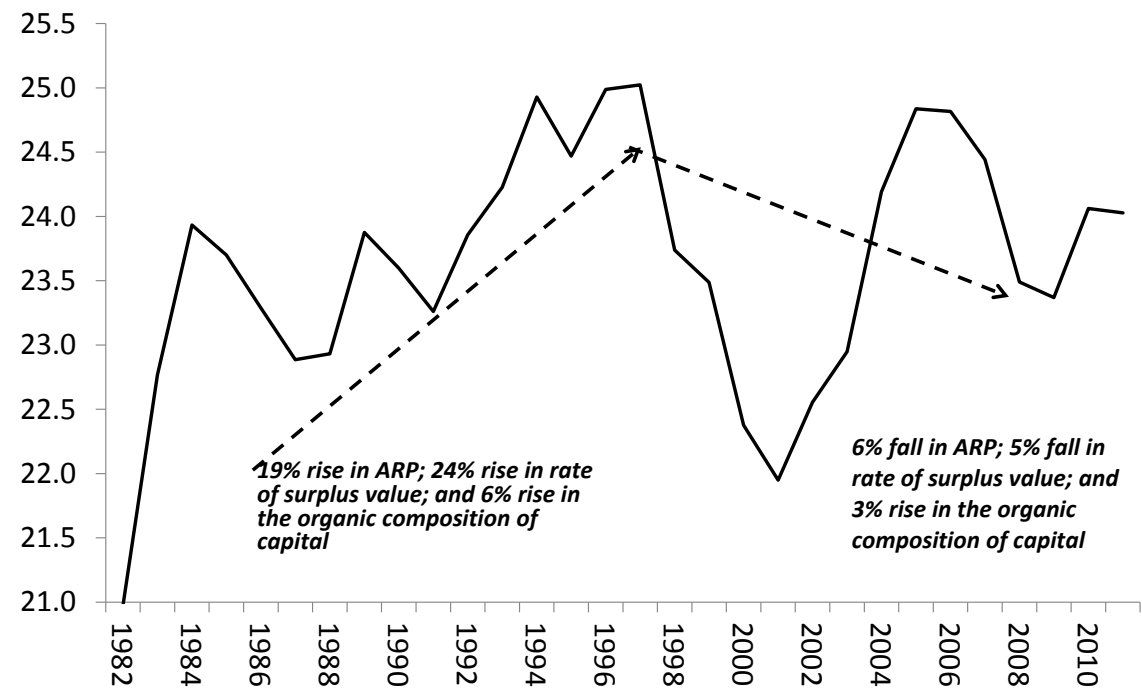

Figure 2 US average rate of profit, 1982-2011

Source: See Appendix.

WRPE Produced and distributed by Pluto Journals www.plutojournals.com/wrpe/ 
the organic composition of capital rose 3 percent. ${ }^{7}$ This laid the basis for the Great Recession of 2008-09. There was a mild contraction in the US economy in 2001, followed by a mild boom up to 2008. Then we had the Great Recession of 2008-09.8 Profitability started to fall in late 2005 (Figure 2).

The slump and the ensuing Long Depression were more severe than anything seen since the 1930s because of the huge build-up of debt and financial assets in the previous two decades (and particularly after 2002). This capital accumulation was what Marx called "fictitious" in that it did not create or represent real value. Instead, there were credit-fuelled bubbles first in hi-tech stocks (crash in 2000) and then in housing (crash in 2007). By 2007, the unproductive financial sector accounted for 40 percent of all US corporate profit. Finally, this credit bubble burst, bringing down the banking sector and the economy. The high level of private sector debt was compounded by the state having to bail out the banks.

Until this overhang of unproductive capital is cleared ("deleveraged"), profitability cannot be restored sufficiently to get investment and economic growth going again. Indeed, it is likely that another huge slump will be necessary to "cleanse" the system of this "dead (toxic) capital." The Long Depression will continue until then. Despite the very high mass of profit that has been generated since the economic recovery began in 2009, ${ }^{9}$ the rate of profit stopped rising in 2011. The average rate of profit remains below the peak of 1997.

But the rate is clearly higher than it was in the late 1970s and early 1980s at its trough. That can be explained by one counteracting factor to the secularly rising organic composition of capital, namely a rising rate of surplus value since $1982,{ }^{10}$ as Figure 3 shows.

The story of US profitability is also repeated for the major capitalist economies. Various studies have shown a similar trajectory for the rate of profit in the major economies. ${ }^{11}$ The latest analysis of the "world rate of profit" incorporating the G7 major economies and the BRICs (Brazil, Russia, India, China) found that there was a fall in the world rate of profit from the starting point of the data in 1963 and never recovered to the 1963 level. $^{12}$

The world rate of profit reached a low in 1975 and then rose to a peak in the mid-1990s. Since then, the world rate of profit has been static or slightly falling and has not returned to its peak of the 1990s (Figure 4). This suggests that the boom of the late 1990s and early 2000s was not based on rising profitability in the major economies, but more on a credit bubble and the growth of fictitious capital.

There is a divergence between the G7 rate of profit and the world rate of profit after the early 1990s. This indicates that non-G7 economies have played an increasing role in sustaining the rate of profit, while the G7 capitalist economies have been suffering a profitability crisis since the late 1980s and certainly since the mid-1990s. 


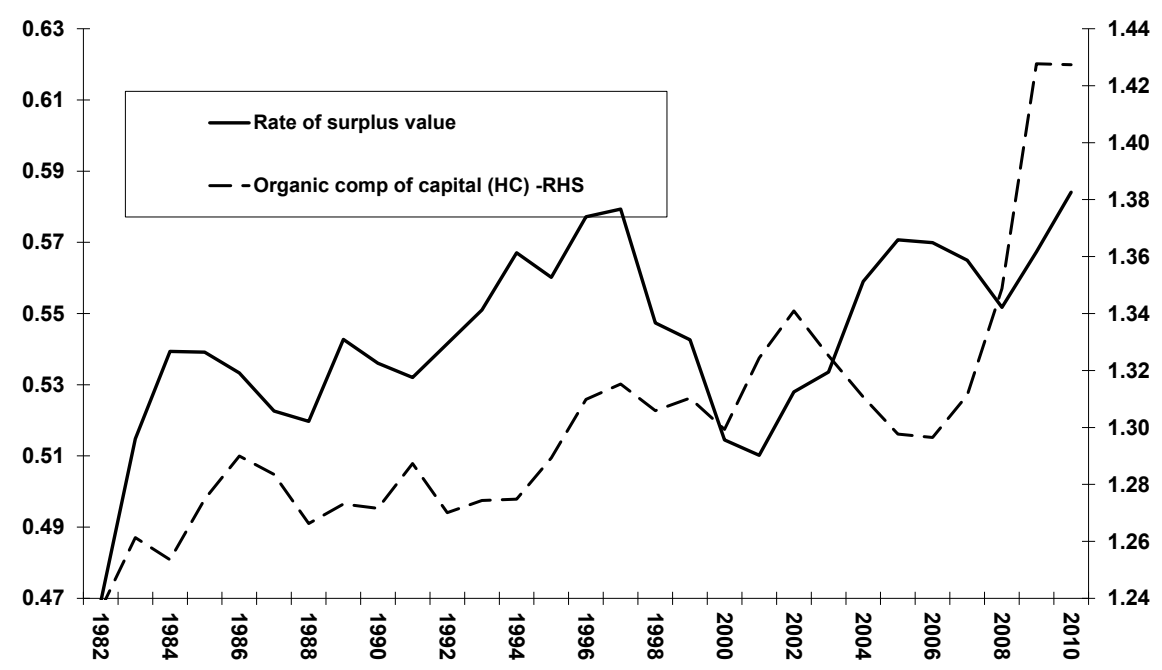

Figure 3 US ratio of surplus value to employee compensation and the organic composition of capital, 1982-2010

Source: As Figure 2, and see Appendix.

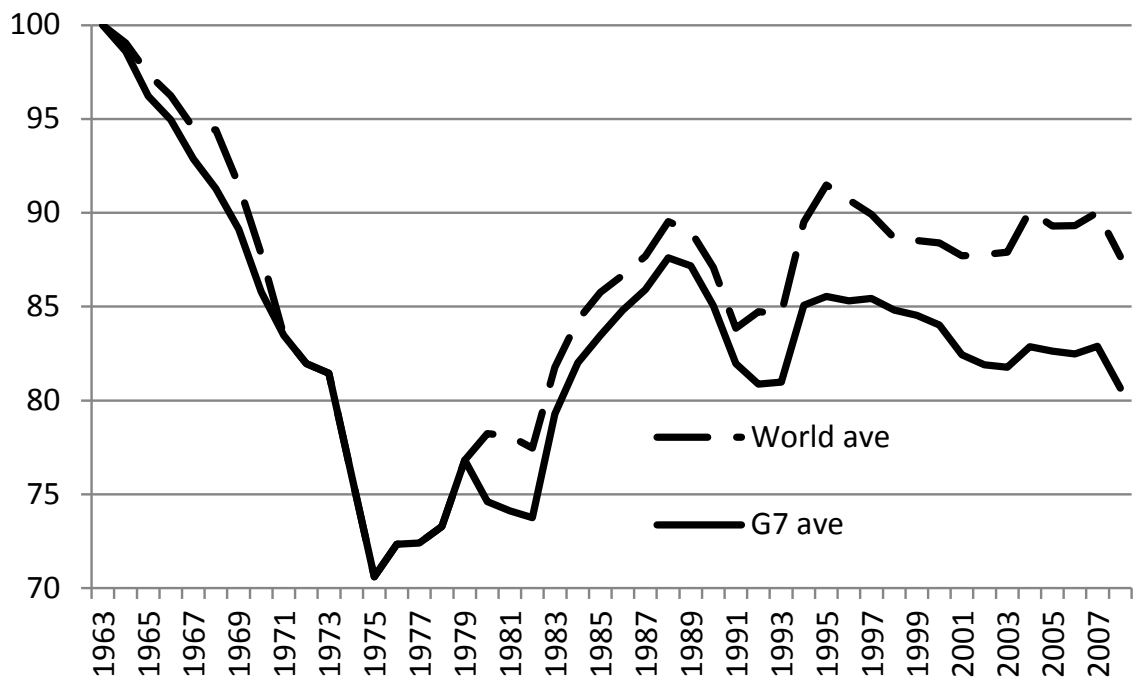

Figure 4 The world and G7 average rates of profit, 1963-2008 (indexed, $1963=100$ ) Source: Roberts (2012). 
Globalization was the major force that enabled the counteracting factors to dominate in the 1990s. Capitalism became truly global in the late 20th century, a period that was similar but way more powerful than in the "globalization" period of the late 19th century. The huge increase in capitalist investment into so-called emerging capitalist economies brought into the capitalist mode of production for the first time a huge supply of peasant and non-capitalist labor, and sometimes at a cost below the value of labor power in the dominant countries, i.e. super-exploitation. ${ }^{13}$

However, the data suggest that the countervailing factors are no longer sufficient to drive up the world rate of profit for now. Further destruction of capital will be necessary through another significant slump in global capitalism to raise profitability. ${ }^{14}$ There is still a long way down to go for US and global capitalism before it reaches the bottom of the current down phase.

\section{The Keynesian Diagnosis}

For Marxists, the key variable in understanding the motion of a modern capitalist economy is the rate of profit. The Marxist analysis recognizes that the underlying cause of the crisis in the first place is to be found in the failure of capitalist production to generate enough profit relative to capital invested. Then, capital must self-destroy to restore profitability and start the whole thing again. This means that a sufficient mass of unprofitable weaker capitals must go bankrupt, old technologies must be replaced by new, more efficient, ones, and sufficient unemployment must be generated. Until that point, it will languish.

The Keynesians do not recognize profit, let alone the average rate of profit (ARP), in the capitalist economy as the key variable. Like neoclassical theory, they start with the concept that capitalist production is for consumption, not profit. Consumption leads to investment in production. Thus the key variables for Keynesians are consumption and investment.

The lack of demand can be caused by wage compression. But Keynesians also rely on factors outside the economic process as an "explanation" of the dynamics of the capitalist economy. If investor and consumer confidence disappears, money is hoarded, demand falls and investment stops. The state is ascribed an important point in stimulating demand.

Keynesian theory concludes that higher profits depend on workers spending more, the economy importing more and, failing that, on government dissaving or net borrowing. So in a slump when households are saving more and spending less, especially less on foreign goods, the Keynes-Kalecki profits equation argues that capitalism can be saved by more government spending, not less. ${ }^{15}$ However, as section 3 will argue, higher wages and thus higher spending by workers can only worsen the crisis. 
Apart from theory, there is no evidence that justifies the view that capitalism is beset by a crisis caused by a lack of demand. Take the US economy. The slumps of 1974-75 and 1980-82 were preceded, not by a fall in wages relative to profits generating a "lack of demand," but the contrary. Yet those major capitalist slumps were preceded by a decline in the average rate of profit for corporate business (Figure 5). After the 1980-82 slump, the average rate of profit rose and wages fell relative to profits. ${ }^{16}$ Yet there was no serious slump for US capitalism after the early 1980s (1990-01 and 2001 were mild compared with 1974-75 or 1980-82). So the data conform to the Marxist theory of crisis and not to the Keynesian.

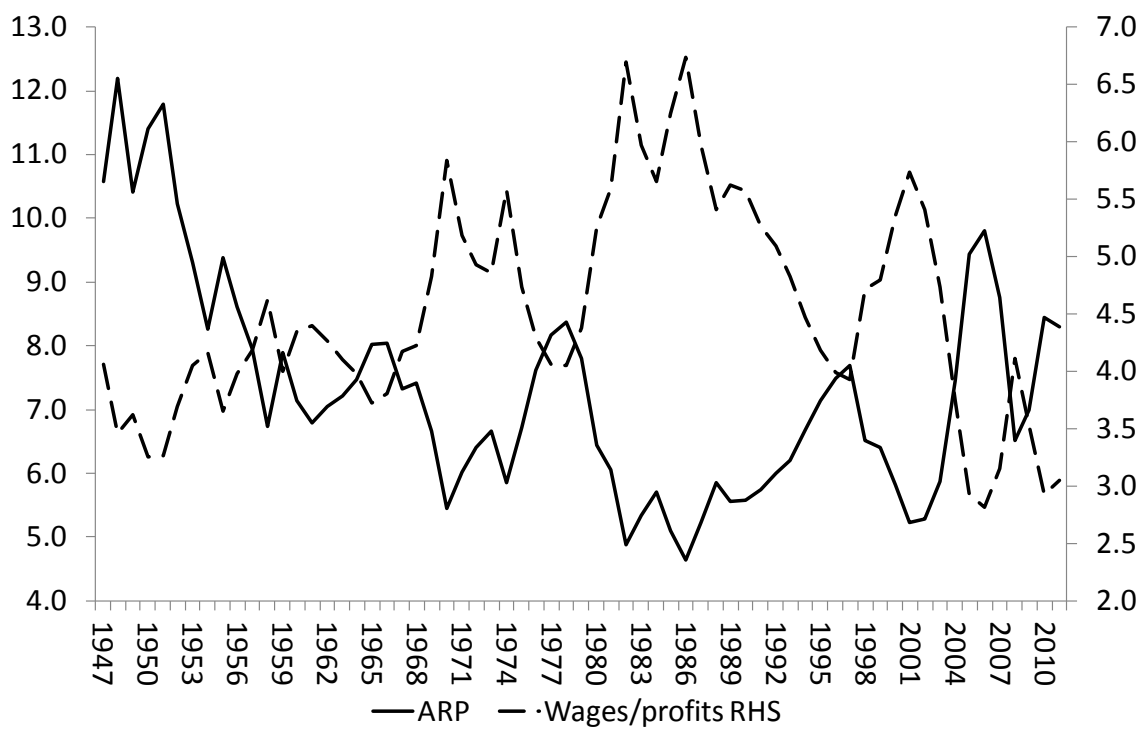

Figure 5 US average corporate rate of profit and wages/profit ratio, 1947-2011 Source: See Appendix.

All previous research on business cycles has concluded that the movement in investment is initially driven by movements in profit, not vice versa. ${ }^{17}$ Our own analysis of the Great Recession confirms the conclusions of this earlier research. Profits fell for several quarters before the US economy went into a nose dive (Figure 6). US corporate profits peaked in early 2006 - that's the absolute amount, not the rate of profit, which peaked earlier in 2005. From its peak in early 2006, the mass of profits fell until mid-2008, made a limited recovery in early 2009 and then fell to a new low in mid-2009. After that, the recovery in profits began and the previous peak in nominal dollars was surpassed in mid-2010. 


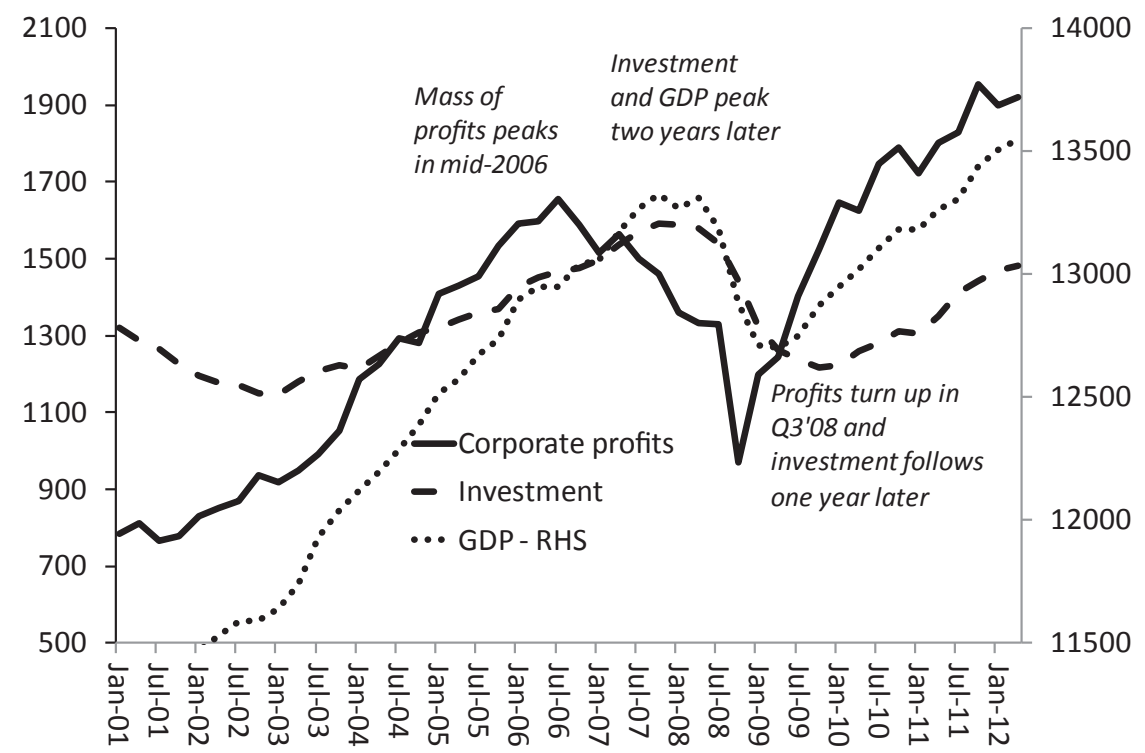

Figure 6 US corporate profits, real investment and GDP Q1-2001 to Q2-2012, \$bn

Source: See Appendix.

What was the reaction of investment to this movement in US profits? When US corporate profit growth started to slow in mid-2005 and then fell in absolute terms in 2006, corporate investment went on growing for a while as companies used up reserves or increased borrowing in the hope that profits would be restored. But when that did not materialize, investment growth slowed during 2007 and then fell absolutely in 2008, at one point falling at a near 20 percent year-on-year rate. Profits started to recover at the end of 2008 but investment did not follow for a year. It was the same for GDP. GDP peaked well after profits did and recovered after profits did. The movement of profits leads the movement of investment, not vice versa. Profits were falling well before the credit crunch began. So the crisis was not due to a lack of "effective demand," but followed the Marxist law of profitability, even if the eventual trigger for the slump was in the financial sector.

\section{The Keynesian Prescription}

But can Keynesian policies restore an economy's profitability and end the slump? Civilian Keynesian policies ${ }^{18}$ can be defined as: state induced; capital financed; redistribution or investment, policies. Let's consider redistribution first. 


\section{State-induced pro-labor redistribution}

Suppose the state brings about a redistribution of value from capital to labor through pro-labor legislation, or progressive taxation, or higher subsidies. Let us assume unsold consumption goods (the assumption behind Keynesian interventionism) and suppose that policies are introduced to raise net wages (direct, indirect and deferred). More consumption goods are sold and labor consumes more. This is why these policies are supposed to be pro-labor. Greater sales also mean fewer losses and thus the recovery of lost profits. The Keynesian argument is that these greater profits can (more than) offset the increased wages, thus initiating the upturn. This is why these policies are supposed to be pro-capital as well. Both capital and labor would gain. This is the reformist character of Keynesian policies.

But does a policy aimed at increasing wages restore profitability? Let us divide the economy into the sector producing means of production (sector I) and that producing means of consumption (sector II).

(a) First, take sector II. Under the most favorable hypothesis for the Keynesian argument, the whole of the wage increase in both sectors is spent on unsold consumption goods (rather than being partly saved). On the one hand, sector II suffers a loss in profit due to higher wages; but on the other, it can sell the unsold means of consumption to its own laborers for an equal price. The numerator of the rate of profit is thus unchanged. But the denominator rises due to the higher investment in variable capital (labor). Labor's consumption increases, but sector II's rate of profit falls.

(b) Now take sector I. Its numerator decreases (because of lower profits due to higher wages) and the denominator rises (because of higher investment in labor power). In this sector too, labor's consumption increases, but the rate of profit falls.

(c) Finally, higher wages in sector I (a loss for capital in sector I) increase the sale of consumption goods to labor in sector I by sector II (a gain for capital in sector II). Sector II's gain is equal to the loss for capital in sector I. There is no change in the two numerators.

Gain and losses in the numerators of the ARP offset each other but the denominators in both sectors rise. So the ARP falls. Wages and thus labor's consumption can increase but the ARP falls, confirming Marx's view.

Suppose now that wages keep rising up to the point where all consumption goods are sold. Supposedly, a further wage rise would spur the extra production of consumption goods and this would stimulate the production of means of production. The economy would be revived. However, production will only increase if both the demand for the extra output and profitability rise. But this is not the case. Pro-labor redistribution raises demand, but lowers the ARP. The Keynesian medicine fails because it assumes that the dynamics of the system depend on consumption rather than on profitability. Even from the Keynesian perspective of profit, where the 
gains deriving from higher sales are supposed to offset the cost of increased wages, Keynesian policies fail because profits do not increase.

Up to here, the implicit assumption has been that the profits are those of enterprises in the productive sectors. The conclusion has been that higher wages lower the firms' profits and profitability. But the brunt of higher wages can also fall on the profits of the firms in the unproductive sectors of the economy (commerce, finance and speculation). In this case, labor gains from redistribution, but this policy threatens to accelerate the burst of the financial bubble. Profits in these sectors can be skimmed, but one should be aware of the consequences: your death, my life!

The brunt of a wage rise could also be borne not by the firm, but by the capitalists' own (unproductive) consumption. Then, a pro-labor redistribution increases labor's consumption but decreases that of the capitalists. Under the assumption that labor has a higher propensity to consume than capital, the investments induced by labor's higher consumption could increase more than the decreased investments caused by capital's reduced consumption. Both productive capital and labor would gain. This argument suggests a supposed community of interests between labor and productive capital against parasitic capital. But it overlooks that, as a rule, net investments do not increase if profitability falls and that, if they do increase, whether the net increase has a higher or lower organic composition than the average, and thus whether the ARP rises or falls as a result (see the Marxist multiplier below).

Most would argue in favor of a redistribution from capitalists' unproductive consumption to labor. This seems self-evident in terms of equity. But that is not the same as concluding that the policy would revive the capitalist economy. Those who think that are not making a distinction between the two sources of surplus value. The economy would not be revived if profits were curtailed in favor of wages either way. If the surplus value or profits are those retained by enterprises, higher wages will reduce those profits and profitability in spite of labor's higher consumption. If the surplus value or profits are those that capitalists distribute to their own unproductive consumption, higher wages cannot revive the economy because of the above.

Some capitalists, the more robust ones, might decide to increase production even at lower levels of profitability. But if profitability keeps falling, eventually they will have to reduce their output. Some other (the weaker) capitalists will go bankrupt and cease production altogether. It follows that capitalists will reduce their output in spite of the higher demand induced by pro-labor policies. ${ }^{19}$

\section{State induced investments and the Marxist multiplier}

The strongest case for Keynesian policies is not the effect on the redistribution of national income but the impact from state induced investments. But the issue that is ignored by Keynesians (and some Marxists who advocate this policy) is: who is 
supposed to finance these investments? There are two possibilities: it can be either capital financed or labor financed. While the distinction is important from the point of view of who pays for these investments, the impact on profitability is relatively independent of which class pays initially for these policies.

Consider capital-financed investments. Let us distinguish between sector I, the producer of public works, and sector II, the rest of the economy. Let's say surplus value, S, is appropriated (e.g. taxed) by the state from sector II and channeled into sector I for the production of public works. ${ }^{20} \mathrm{~S}$ is the loss for sector II and a deduction from its surplus value. Having appropriated S from sector II, the state then pays sector I a certain profit, $\mathrm{p}$, and advances the rest, $\mathrm{S}-\mathrm{p}$, to sector I for the production of public works.

The state receives public works from sector I to the value of $\mathrm{S}-\mathrm{p}+\mathrm{p}^{*}$, where $\mathrm{p}^{*}$ is the surplus value generated in sector I (whether $\mathrm{p}^{*}$ is equal to $\mathrm{p}$ or not). Sector I realizes its profits because it has received $\mathrm{p}$ from the state, while $\mathrm{p}^{*}$ belongs to the state. Sector II loses S but sector I gains $\mathrm{p}$. In sum, private capital loses S-p to the state and the numerator of the ARP decreases by that much. So, initially, the ARP falls. In the case where labor finances the public works through taxation, the ARP rises because both capitalist sectors receive a share of the value of labor as surplus value.

But whether it is capital or labor that finances public works, the final outcome of these policies on the ARP will depend on what we call the Marxist multiplier. ${ }^{21}$ To produce public works, sector I purchases labor power and means of production from other firms in both sectors. In their turn, these firms engage in further purchases of means of production and labor power. This multiplier effect cascades throughout the economy.

Under the most favorable hypothesis for the Keynesian argument, the state induced investments are sufficiently large to absorb the unsold goods and then stimulate new production. But given that the firms involved in the cascade effect have different organic compositions, three outcomes are possible for the ARP.

(a) The initial investment by sector I (whether capital financed or labor financed) plus the further investments induced by it are such that their organic composition is equal to that of the whole economy. Then the rate of profit generated is equal to the economy's average. The ARP after these investments does not change. The policy fails to raise the ARP.

(b) Alternatively, the chain of investments stops at a point at which the organic composition of all the invested capitals (including the initial ones) is higher than the average. This is the most likely outcome, given that new investments tend to incorporate new technologies with higher organic composition. The ARP falls and so the policy fails. The reason why the higher organic composition of this aggregate worsens the crisis is that the extra investments have gone predominantly to the most 
efficient firms (those with higher organic composition). They, by selling their higher output at the same price as that of the lower output of the laggards, appropriate value from the latter and eventually push them out of the market, thus worsening the crisis.

(c) In the opposite case, where the average organic composition falls because of these investments, the ARP can rise. But then the Keynesian policy has helped the less efficient capitals, those with lower organic composition (and thus lower efficiency) to survive. In this case, this policy only postpones the slump instead of ending it.

Most important, all the three possible outcomes are not policy options that can be determined a priori by the state. After the initial investment, the final result in terms of organic composition and ARP depends on the spontaneous working of the system. The state can influence only the first step, by appropriating value either from labor or from capital and by initially commissioning public investments to low or to high organic composition capitals. Figure 7 provides a summary of the assessment of Keynesian policies.

\section{Would monetary policies help?}

Some Keynesians propose to stimulate demand neither through state redistribution nor through state-induced investments but by increasing the quantity of money. ${ }^{22}$ The assumption is that the ultimate cause of crises is a lack of "effective demand" so that a higher quantity of money in circulation could stimulate demand, investments and growth.

Consider first empirical evidence. Figures 1, 4, and 5 show unmistakably the secular falling trend in the ARP. If monetary policies have failed for more than 60 years to reverse the trend, why would they succeed now? Indeed, there is no reason to think they would. First, inasmuch as money is actually printed, no new (surplus) value is created. The economy cannot restart if, in spite of higher demand, the surplus value produced relative to the capital invested is unchanged. Printing money merely only increases the representation of value and thus of surplus value rather than (surplus) value itself. By printing money, the state redistributes value already produced but no new (surplus) value is generated. We have seen that pro-labor redistribution cannot offer a way out of the slump. We shall see below (section 4) that even pro-capital redistribution cannot do that either.

Second, by "printing money" what is really meant is expanding credit. The notion that credit is money is almost universally accepted and yet fundamentally wrong. By creating credit, one does not "create money out of nothing," an absurd proposition. Out of nothing, one can create nothing. By creating credit, one creates debt, not money.

Central banks have increased the supply of money globally (power money), but the quantity of this money is tiny compared to the growth of credit or debt in the 

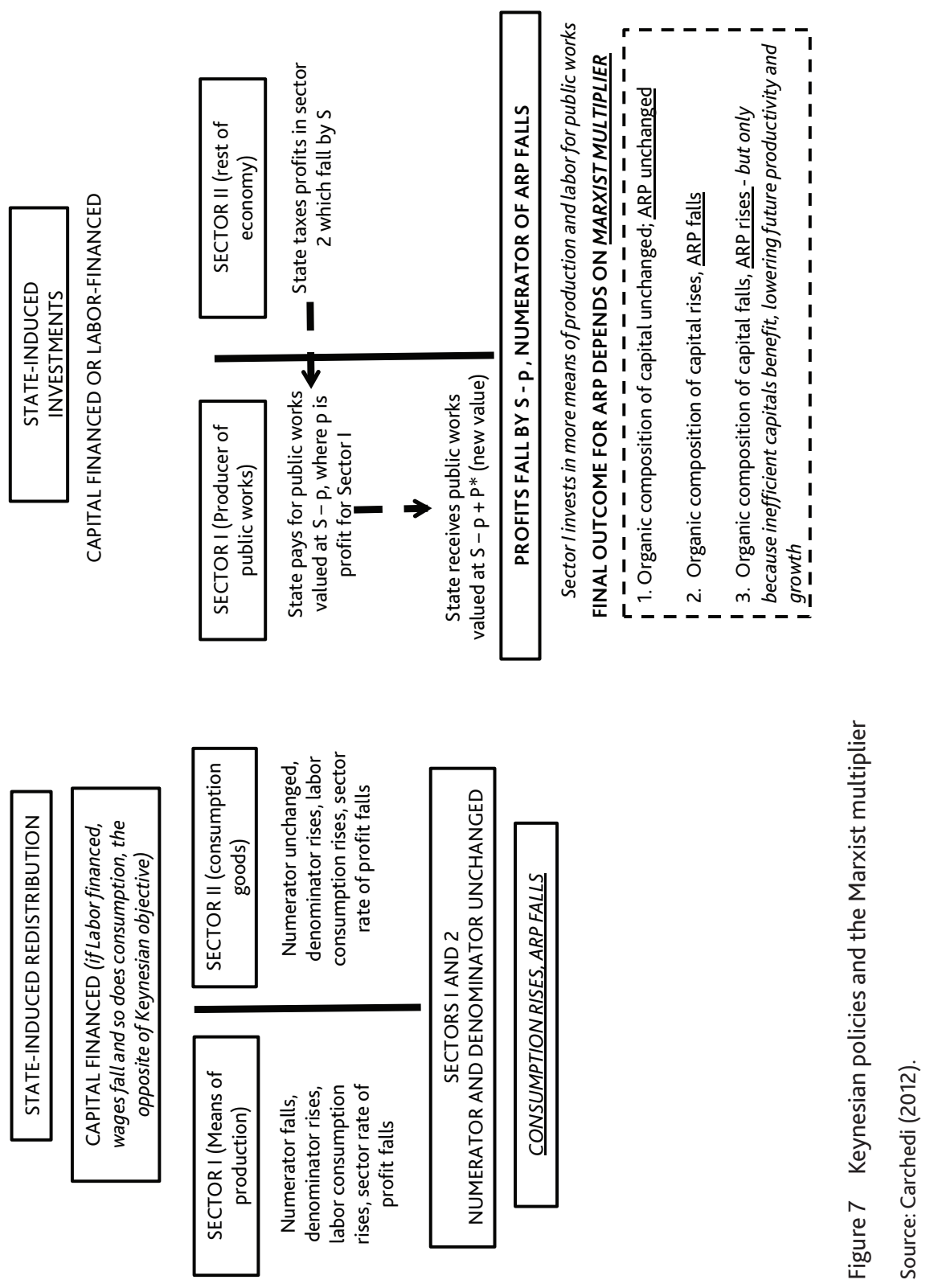

WRPE Produced and distributed by Pluto Journals www.plutojournals.com/wrpe/ 
form of bank loans, debt securities and their derivatives. Power money has risen from 4 percent of world GDP in the late 1980s to 11 percent now. But all forms of credit started at 150 percent of world GDP and are now over 350 percent of global GDP, some 30 times larger than power money (see Figure 8).

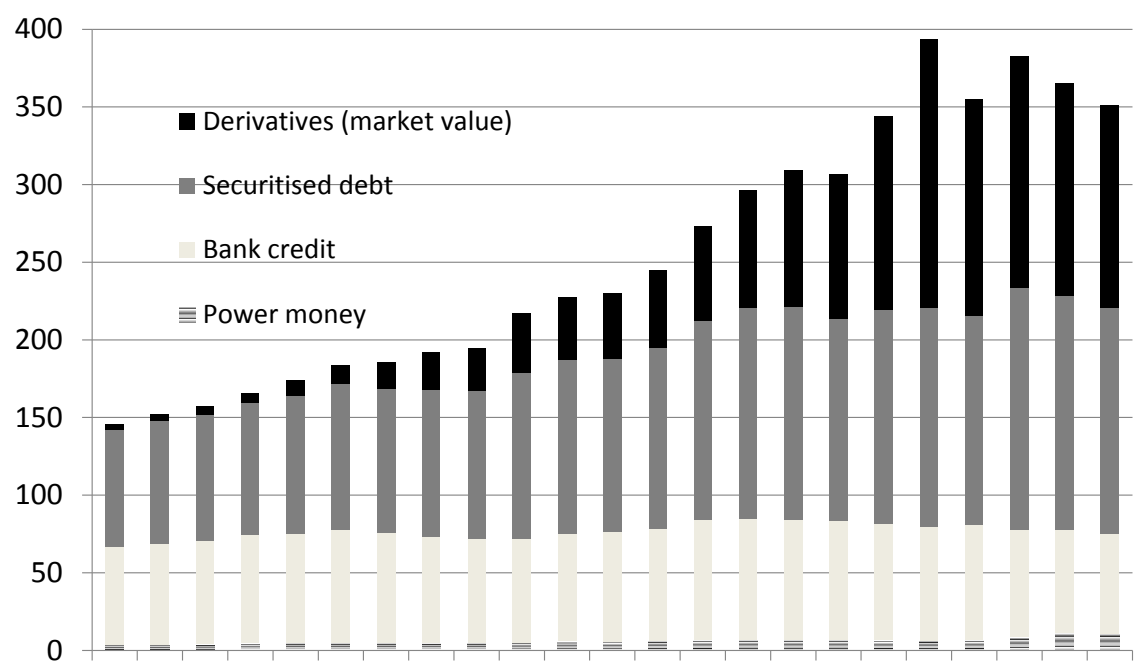

8990919293949596979899000102030405060708091011

Figure 8 Global liquidity as \% of world GDP, 1989-2011

Source: Roberts (2012b), and see Appendix.

Eventually debts must be repaid. So credit expansion only postpones a crisis to the moment of debt repayment. The Keynesian argument is that debts can be repaid when, possibly due to the Keynesian policies, the economy restarts and the appropriation of the surplus value needed for debt repayment no longer threatens the recovery. But this is wishful thinking. Pro-labor redistribution compresses profitability and thus worsens the crisis. State induced investments can in principle raise profitability but this is not a way out of the slump but merely a postponement of the eruption of the crisis. By postponing the recovery, the policies are an obstacle to, rather than being a condition for, the repayment by the state of its debt. ${ }^{23}$

The crisis must itself create the condition of its own solution, namely the destruction of capital. Only when sufficient (backward) capitals have been destroyed (have gone bankrupt), can the more efficient productive units start producing again on an enlarged scale. It follows that, if Keynesian policies postpone the impact of the crisis, they also postpone the recovery.

The idea that state induced investment policies, possibly through state borrowing, could start a sustained recovery, provided the scale is sufficiently large, is not only 
theoretically invalid (as we have tried to outline above) but it is also empirically unsubstantiated. The example usually mentioned is the long period of prosperity that followed the Second World War, the so-called Golden Age of capitalism. Supposedly Keynesian-style policies through government borrowing (budget deficits) made it possible to kick-start the long period of prosperity of 1946-70. But US gross federal debt as a percentage of GDP actually decreased during the Golden Age from 121.7 percent in 1946 to 37.6 percent in 1970. The long spell of prosperity was not due to credit creation, but due to the reconversion of military into civilian capital and to the liberation of pent-up purchasing power after the war. ${ }^{24}$

\section{Would competitive devaluation help?}

Another tenet of Keynesian theory is the almost religious belief that for weak countries devaluation provides the way out of the crisis or at least mitigates it. This point is particularly important for the weaker Eurozone countries. Elsewhere, we consider as an example the comparison between Germany and Italy. ${ }^{25}$ We conclude that Germany owes its superior performance on the international markets to its greater productivity.

Italy (or other weaker Eurozone countries) could compete with Germany by leaving the euro, reverting to the lira and to competitive devaluation. However, it would be mistaken to think that devaluation could spur greater productivity and economic growth, greater employment, higher wages, better living conditions for labor, and so lead Italy or other weaker countries out of the slump. If Italy devalues, more lire are exchanged for each euro. Italian commodities are sold to Germany at below their pre-devaluation euro price and thus a part of Italy's commodities are appropriated by Germany for free. In terms of use values, the lost commodities contribute not to Italy's consumption and investment but to Germany's. In terms of value, Italy loses to Germany the value and surplus value contained in those commodities. So initially, Italy's ARP falls while that of Germany rises.

What are the consequences for labor? Employment might increase if the extra export consists not of unsold commodities but of newly produced ones. But the rate of exploitation increases as well. In fact, the capitalists try to compensate for the loss of profits by raising the rate of exploitation of the increased employment. Also, while labor's purchasing power grows due to the extra employment spurred by the greater production for export, there are fewer wage goods available on the national market. This can lead to inflation. Either the prices of wage goods increase or wages must be reduced. Competitive devaluation, to be successful, requires an increase in the rate of exploitation.

The ARP falls initially because of the exporting firm's loss of surplus value. However, the final outcome for the ARP from the extra production induced by devaluation depends on whether labor is subjected to extra exploitation and on the 
Marxist multiplier. As argued above, the chain of extra investments spurred by this extra production can either raise the organic composition, thus lowering the ARP, or lower it, thus raising the ARP. But in this case, it is the less efficient capitals that are kept alive. ${ }^{26}$

In sum, through competitive devaluation, production and employment in the exporting firms rise. Therefore, both the GDP and the balance of trade of the exporting country improve. However, these results are short-term because the exporting country loses value and surplus value to the importing country so that the former's growth is hindered rather than stimulated. This longer-term negative result is hidden behind the short-term improvement.

As for the ARP, the fall inherent in the loss of use values and of the (surplus) value contained in them might be offset by the positive effect on the ARP of the Marxist multiplier. But then as seen above, the crisis is only postponed. Labor is worse off because although employment rises, the rate of exploitation rises too. On balance, the short-term improvement in production, employment, GDP, and the trade balance (these are the indicators conventional economics focuses upon) hides the lower real wages and the greater rate of exploitation of labor, the loss of value, and either the immediate fall in the ARP or the postponement of this fall (a temporary rise). In spite of appearances, the consequences of competitive devaluation are negative both for capital and for labor; if not immediately, in the longer-term.

\section{Austerians vs. Keynesians}

Nowadays, the dominant economic theory is the Austerian one. For it, the cause of crises is too high wages. To assess this thesis, we must start from a period of high profits. In fact, if we started from a period of low profits, we would assume a period of crisis, which is what we want to explain.

Now, if wages start to rise, profit can either rise less or fall. There is no reason to assume that wages necessarily rise to the point at which profits (or the ARP) fall. This theory is thus indeterminate. Greater wages cause a fall in profits only if the quantity of the new value generated is either stagnant or decreasing. But then that assumes what has to be explained. Once the crisis has begun, higher wages worsen it. But what worsens the crisis is not its cause. This is the root cause of neo-liberalism's mistake.

What the Austerians propose are in effect various forms of pro-capital redistribution. They urge reductions in budget deficits and levels of public debt, obviously by cutting wages. They oppose "quantitative easing" and instead propose to hike interest rates at the first opportunity. The purpose of these policies is clear: to restore profitability through a shift of value from labor to capital, while at the same time avoiding policy measures that interfere with the working of the market. 
If higher wages are not the cause of the crisis, wage compression cannot be its cure. This is not because of the reasons advanced by the Keynesians, namely because reduced demand, caused either by private capital or the state, worsens the crisis. It is true that wage containment causes difficulties in realization, first in the sectors producing wage goods and then in the rest of the economy through reduced profits. But lower wages also mean higher profits. And as we have seen above, even when all the consumption goods equal to the wage cut remain unsold, gains and losses compensate each other. From a Marxist standpoint, the numerator of the ARP is unchanged but the ARP rises due to lower investments in labor power reducing the denominator.

However, the economy cannot restart in spite of higher profits and profitability due to difficulties in realization as wages have fallen. So capital's challenge is to invest rising profits in sectors other than wage goods. One possibility is to invest in the means of production for the means of consumption. But then the realization problem in sector II would only be postponed. Or capital could shift to investing in the means of production for the means of production, for example, in the construction of factory buildings. However, the demand for such commodities would eventually decrease (you cannot keep constructing factory buildings without putting them into use) and realization problems would then appear in this sector as well. Moreover, the more profitability falls due to the rising organic composition of capital from investing in this sector, the less is capital's incentive to invest.

Eventually demand falls across the board. Then the extra profits are either set aside as reserves (hoarded) or invested in the unproductive sectors (commerce, finance, and speculation) where profitability is higher. On the one hand, this transfer to unproductive sectors contributes to the inflation of the financial bubble. On the other, reduced accumulation in the productive economy lowers the creation of newly generated surplus value. Tax revenues fall and state finances deteriorate. When both pro-capital redistribution and the production of new (surplus) value turn down, the bubble bursts. And when the financial bubble bursts, the state is forced to appropriate increased value from labor to rescue the financial (banking) system. The real economy deteriorates because of increased state taxation and the collapse of speculation and the financial sector generating closures and unemployment.

So wage containment, neo-liberalism's card against the crisis, can only postpone the crisis. And once the crisis starts, more sacrifices by labor cannot expand reproduction in the productive economy. A rising state debt ratio to GDP is not initially caused by wage cuts and lower consumption (Keynesian fashion) leading to slowing GDP growth. Rather, it is falling profitability and reduced accumulation in the productive economy (both because less profits are available for recapitalization and because a greater portion of those lower profits is unproductively invested) 
that causes slowing growth, rising unemployment and lower wages, i.e. lowering labor's purchasing power.

Yet Keynesian economists perceive state induced "austerity" (an ideologically laden word that should be carefully avoided) as the cause of the crisis. For example, Stiglitz criticizes austerity policies to the effect that wage cutbacks reduce income and thus profitability. ${ }^{27}$ If wage cuts were the cause of the crisis, the slump could be countered by raising wages. Both capital and labor would gain. This is the basis of Keynesian reformism. But if wage cuts just postpone the crisis, in the long run, the policy is useless. In sum, the tendency towards crisis will operate whether wages increase (because profitability falls) or decrease because the greater profits are diverted towards unproductive investments.

Supporters of austerity like to cite the example of the Baltic states as showing that these policies will quickly restore profitability and growth. ${ }^{28}$ The government there adopted neo-liberal policies forcefully. Estonian unemployment fell back from 20 percent in early 2010 to just(!) 10 percent now and the economy grew at over 8 percent in 2011. But Estonia's real GDP is still some 9 percent below its peak in 2007, having fallen over 17 percent from peak to trough.

The real aim of austerity is to achieve a sharp fall in real wages and cuts in corporate taxes and thus raise the share of profit. The Estonian labor force has been decimated as thousands left this tiny country to seek work elsewhere in Europe. Estonia also received over $€ 3$.4bn in EU structural funds to finance infrastructure spending and employment. In this way, wage costs have been lowered and profits raised.

That other poster child for "successful austerity," Ireland, has achieved a partial export-led recovery by getting rid of its "excess" workforce in a similar way. Irish emigration is now back at levels not seen since the dark days of late 1980s.

Greece is not tiny like Estonia, but it is a relatively small capitalist economy, dependent on trade, mainly of processed minerals, pharmaceuticals and food, as well as services like tourism. Austerity in Greece is supposed to be aimed at the public sector. But the reality is that it is private sector workers that have been hit the most. Public sector employment shrank by some 56,000 from 2009 to 2011, a 7.8 percent drop. Private sector employment (a much larger share of the labor force) is down 13 percent. And labor costs are down 18.5 percent. This is the real target of austerity.

We estimate that the Greek rate of profit peaked in 2007 some two years before the crisis really hit Greece. Investment then plummeted 50 percent from 2007 to now (Figure 9). Austerity has driven the rate of surplus value up by 25 percent since 2009. But Greek capitalism is still encumbered by inefficient capitals and the organic composition of capital remains elevated. So investment is not yet recovering. 


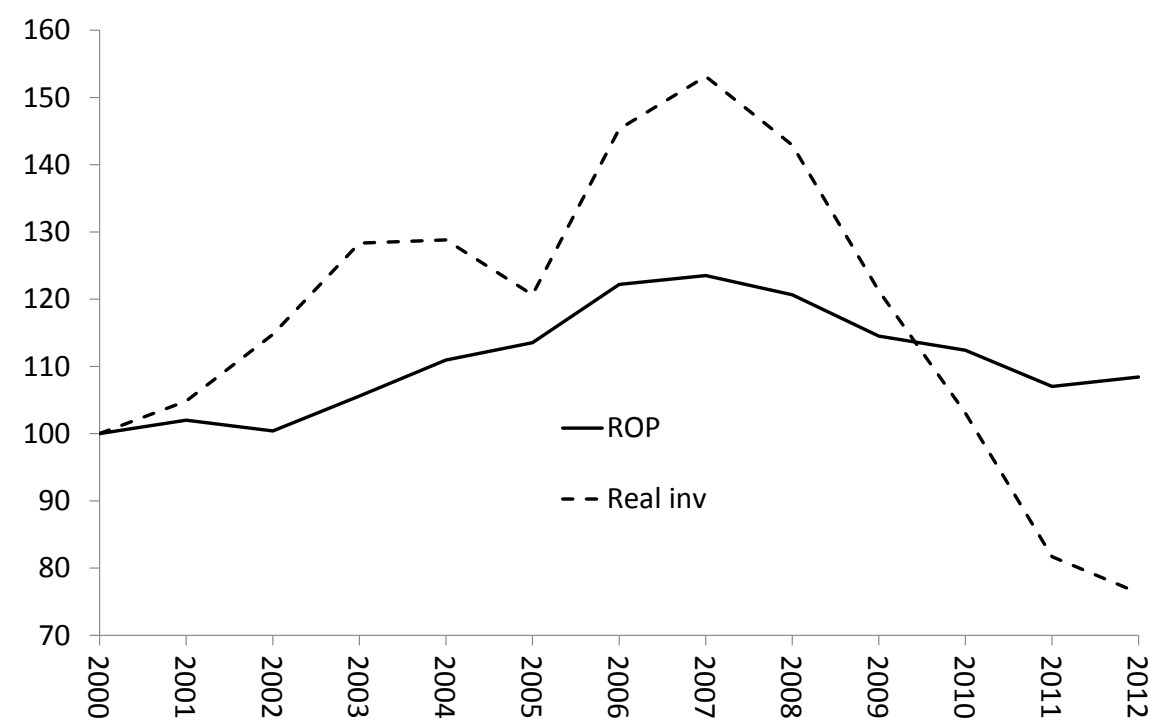

Figure 9 Greek rate of profit and business investment since 2000 (indexed, $2000=100$ ) Source: See Appendix.

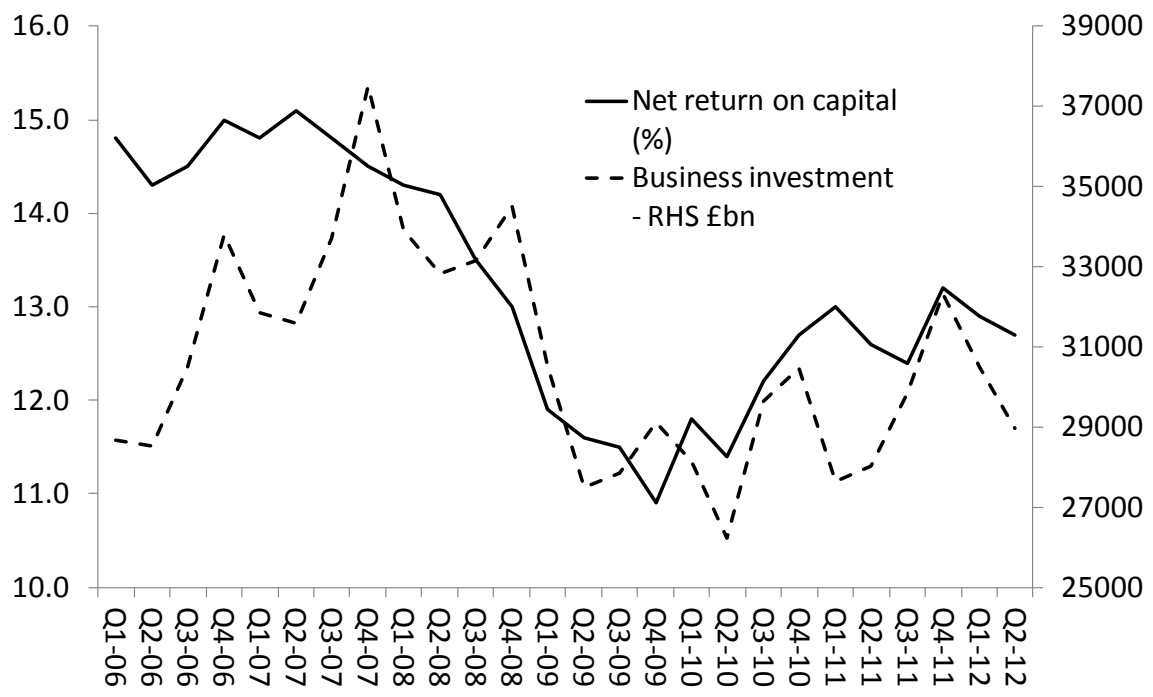

Figure 10 UK rate of profit and business investment since 2006 (\%)

Source: See Appendix.

WRPE Produced and distributed by Pluto Journals www.plutojournals.com/wrpe/ 
The UK economy is the largest one where the government claims that austerity is the best (only) policy that will work. So far, it is failing. Far from the budget deficit coming down, it was larger in the fiscal year to April 2013 than in 2012 and the gross public debt to GDP is heading towards 100 percent of GDP. Government tax revenues are just not meeting targets because the UK economy is teetering on recession. And most important, unlike the US, UK profitability has not recovered since the Great Recession (Figure 10). And that is keeping business investment low.

Keynesians think that the economy can be revived by the Fed raising "expectations" (falsely), along with more government spending, if necessary by more borrowing. The Austerians reckon that adding to debt will prolong the crisis. The Keynesians disagree..$^{29}$ Both sides continue to focus on the financial sector as the root cause of the slump and not on the productive sectors that create (not enough) surplus value. Marxists reckon that you can tinker with more or less money creation, but it will have little effect if the productive sectors of the economy are not recovering sufficiently to get investment and employment up.

This is the lesson to be drawn from Argentina in 2001, our case study.

\section{What Can We Learn From Argentina?}

Within the context of the present euro crisis, Argentina is often mentioned as a success story based on Keynesian pro-labor redistribution policies and on competitive devaluation..$^{30}$ The fixed convertibility of the peso to the dollar was introduced in 1991 and was revoked ten years later. That decade can be subdivided into a first period (1991-97) of relatively high economic expansion and a second (1998-2002) of economic crisis. The crisis reached its apex in 2001 and recovery started in 2002. What is important for our purposes is what caused the crisis in 2001 and then the rebound in 2002 .

In 1997-98, the economy entered the crisis. The data in Table 1 reveal its severity. Behind these data there is a falling profitability. Michelena (2009) shows that the ARP had been falling since the early 1960s and rebounded around 1985 .

Table 1

\begin{tabular}{lrcc}
\hline Argentina & GNP & Capital accumulation & Un-and under-employment \\
\hline 1997 & $8.1 \%$ & $3.7 \%$ & \\
1998 & $3.9 \%$ & & $26.5 \%$ \\
1999 & $-3.4 \%$ & & $38.9 \%$ \\
2002 & $-10.9 \%$ & $-2 \%$ & \\
\hline
\end{tabular}

Note: The rate of accumulation is the rate of growth of gross fixed capital stock less residential constructions. 


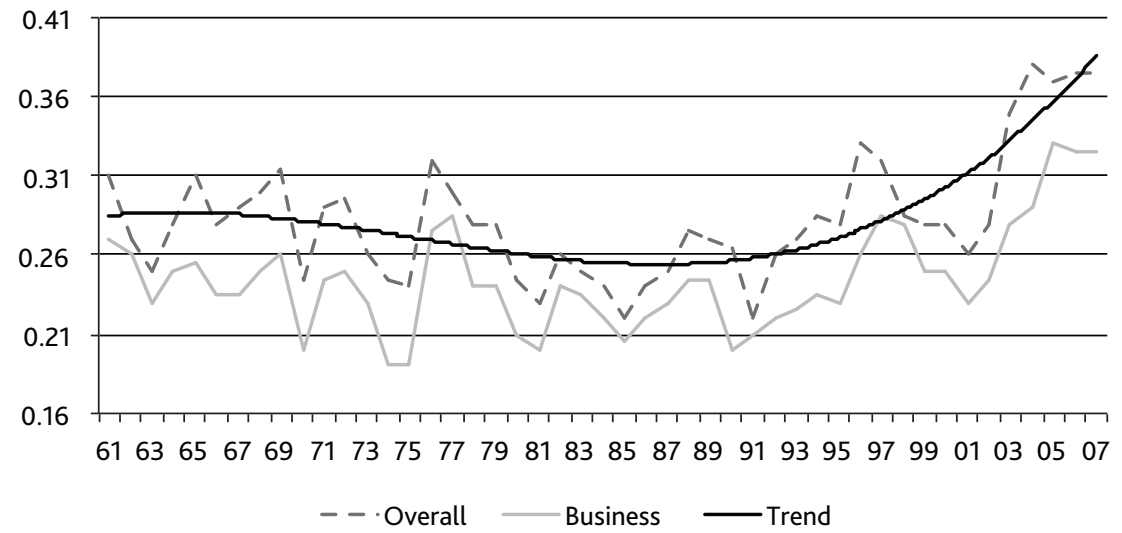

Figure 11 Argentina: rate of profit, 1961-2007

Source: Michelena (2009), chart 1, p. 90.

A broadly similar movement is visible in Figure 12 that shows a tendential fall in the ARP from 1967 to 1989 and an upward movement since then. This figure shows the interplay between the average rate of profit (ARP) on the one hand and the organic composition of capital (OCC) and the rate of surplus value (ROSV) on the other. While the organic composition rises tendentially over the whole period, the ARP rises also tendentially because of the big leap towards the end of the 1980s due to a greatly rising rate of surplus value. More specifically, several turning points are visible.

- From 1963 to $1968-69$, the ARP rises in spite of a rising OCC because of a large increase in the ROSV. The increase in the ROSV overpowers that of the OCC.

- From 1968-69 to 1980, the ARP falls because the OCC rises while the ROSV rises less. The increase in the OCC predominates.

- From 1981 to 1990, the ARP rises in spite of a slight fall in the ROSV because of a greater fall in the OCC.

- From 1990 to 1995, the ARP rises sharply in spite of a rising OCC because of a great increase in ROSV.

- From 1995 to 2001, the ARP falls because, while the OCC rises, the ROSV falls.

- From 2001 to 2003, the ARP rises in spite of a rising OCC because of a greater increase in the ROSV (40 percent according to our estimates).

- From 2003 to 2007, the ARP falls in spite of a fall in the OCC because of a greater fall in the ROSV. 


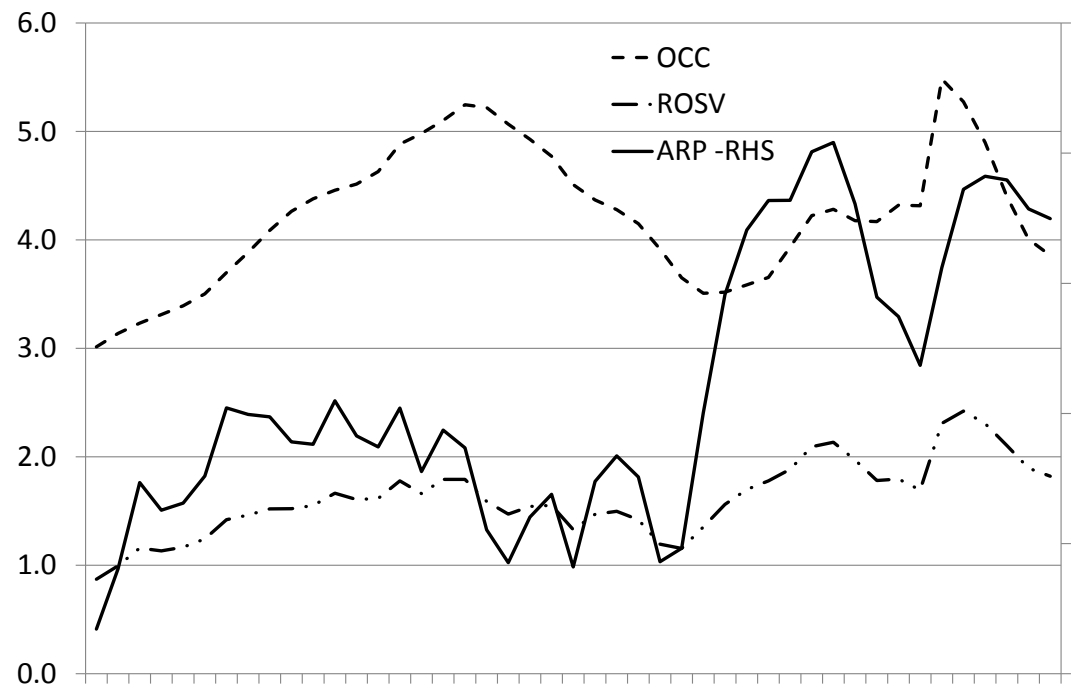

6365676971737577798183858789919395979901030507

Figure 12 Argentina: ARP, OCC and ROSV, 1963-2007

Source: Extended Penn World Tables 2011, authors' calculations.

These data show that the financial crisis of 2001 was preceded by a six-year fall (1995-2001) in the ARP due to a previous ten-year rise in the OCC, starting around 1990, and to a six-year fall in the ROSV, starting from 1995. In its turn, the fall in the ARP for the economy as a whole has been the result of falling profitability in the productive sector. The decade-long rise in the OCC meant that many businesses had closed or had gone bankrupt. "All sectors were contracting, with the exception of finance and banking and of the foreign companies that were running the privatized public services" (Tognonato 2005: 18).

As a result of the crisis, in 2001 and 2002, about 3,000 firms closed down (Ghigliani 2002). In the same period, wages fell dramatically: "In 2001, the laborers lost 32 percent of their purchasing power" (ibid.). In 2002, "more than half of the Argentineans went hungry" (ibid.). ${ }^{31}$

Capital is essentially a production relation, so bankruptcies and decreased capital accumulation coupled with falling employment in that period constituted a destruction of productive capital. The ARP fell from 40.4 percent in 1997 to 31.8 percent in 2001 according to our own estimates. ${ }^{32}$ So the crisis of profitability ignited the financial crisis (rather than the other way around) and Argentina defaulted on its sovereign debt of $\$ 132 \mathrm{bn}$ in the last week of 2001 . This constituted a destruction of financial capital. In January 2002, fixed convertibility was abandoned. The peso devalued from parity with the US dollar to 4 pesos to 1 dollar. 
The recovery started in 2002, right after the explosion of the financial crisis. The default was certainly an important factor. ${ }^{33}$ However, for the Keynesians, two other factors were more important. First, there was the devaluation of the peso, which made Argentine exports cheap and (more) competitive abroad, while discouraging imports. Second, there was pro-labor redistribution, i.e. the large amounts of money set aside for social welfare by the Kirchner administration (higher wages for the lowest-paid laborers, the easing of conditions for house mortgages, etc.). It is argued that these are the reasons for Argentina's recovery—namely Keynesian policies.

Yet Argentina's exports started to decrease after an initial jump in 2002, while the ARP increased tendentially up to 2006-07 (see Figures 11 and 12). So the longer-term rise in the ARP cannot be ascribed to the one-shot competitive devaluation. As for pro-labor redistribution, while the ARP recovered as early as 2001, wages only started to grow in 2003, after recovery had started (Figure 13). ${ }^{34}$ The workers' share in added value too started to increase in 2003 after a fall from 37 percent in 1993 to 29 percent in 2003 (Figure 14). But the ARP started to fall approximately at the same time, contrary to the Keynesian assumption but conforming to Figure 12 above.

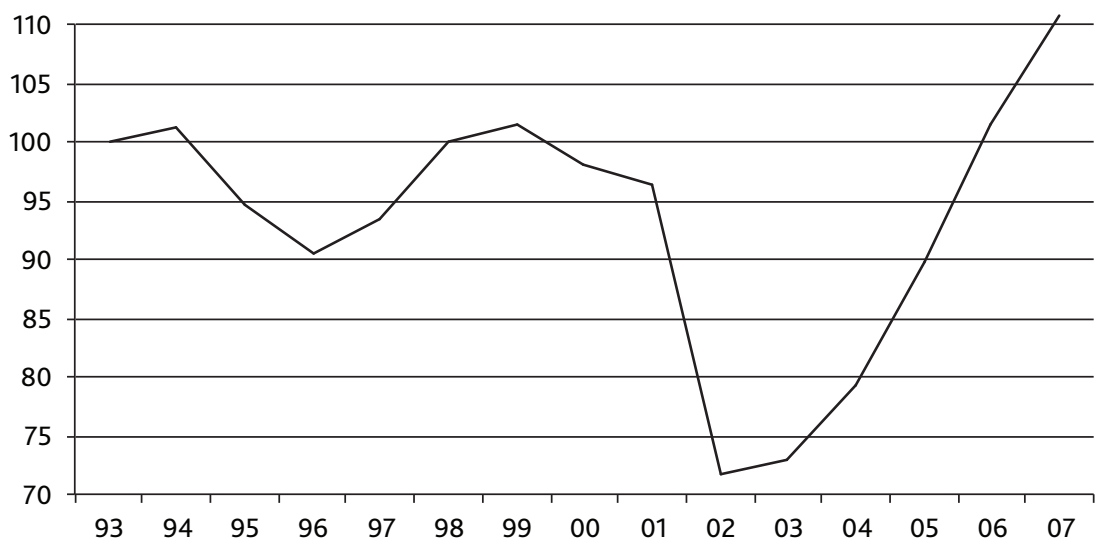

Figure 13 Argentina: index of real average wages, 1993-2007

Source: Extended Penn World Tables 2011, authors' calculations.

What, then, revived the Argentine economy? First, the devaluation of the peso stimulated import substitution by the better-equipped domestic firms. A very significant portion of traditional local producers disappeared. The outcome was a destruction of the less efficient capitals in the manufacturing sector (Ghigliani: 33-34) and a greater degree of competitiveness on the foreign markets. Second, privatization meant the re-creation of private capital in the productive sphere. 


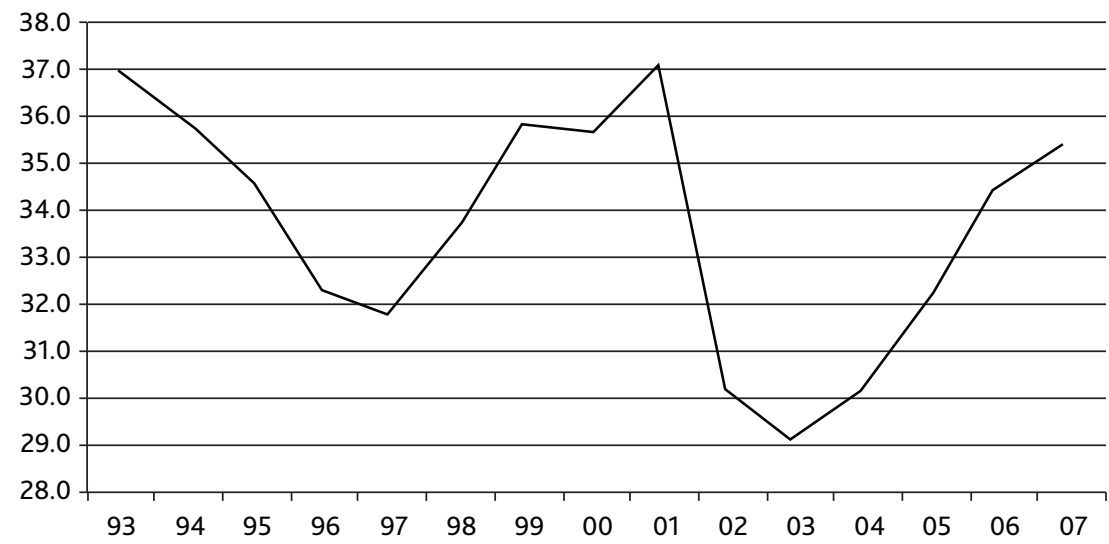

Figure 14 Argentina: share of wages in value added, 1993-2007

Source: Extended Penn World Tables 2011, authors' calculations.

Economic indicators started to improve. According to Michelena (2009), investment as a percentage of GNP grew from 11.3 percent in 2002 to 23.1 percent in $2008 .{ }^{35}$ Greater investment caused an increase in the rate of accumulation. After an initial fall of 2 percent in 2002, it rose 5.1 percent in 2006. This caused a fall in the rate of under-employment from 38.9 percent to 21.4 percent in the same period. Employment rose more than capital accumulation and so the organic composition of capital fell. Industrial production grew by an average rate of 7.9 percent between 2002 and 2009. GNP rose 8.8 percent in 2003 and hovered around that growth rate until 2007.36

But while these indicators were rising, the falling ARP was preparing the next crisis. Between 2003 and 2007 the ARP fell in spite of a falling organic composition because of a lower rate of surplus value.

Our conclusion is that Argentina's recovery was fuelled neither by devaluation nor by redistribution policies, but by the re-creation of previously destroyed private capital in the private sector with a low organic composition; a rising rate of exploitation; and improved efficiency. This is the cause - rather than Keynesian policies - of Argentina's economic revival.

\section{Appendix: Sources and Methods}

Figure 1. The ARP has been smoothed into a ten-year rolling average. The data are based on Figure 2's data from the US BEA NIPA tables.

Figure 2. The US ARP measure is based on the whole economy. 
Profits $=$ net national product $($ BEA NIPA table 1.7.5) less employee compensation (BEA NIPA table 6.2).

Constant capital $=$ historic cost net fixed private non-residential assets (BEA NIPA table 4.1).

Variable capital $=$ employee compensation $($ BEA NIPA table 6.2).

Figure 3. The rate of surplus value $=$ profit divided by variable capital.

Organic composition of capital $=$ constant capital divided by variable capital.

Figure 4. Data sources and methods can be found in Roberts (2012).

Figure 5. Profits are from NIPA tables 6.17A, 6.17B, 6.17C, 6.17D: corporate profits before tax by industry. In the first three tables, utilities are excluded.

Fixed assets. The definition is "equipment, software, and structures, including owner-occupied housing" (http://www.bea.gov/national/pdf/Fixed_Assets_1925_97. pdf). The data considered in this paper comprise agriculture, mining, construction, and manufacturing (but not utilities, see above). Fixed assets are obtained from BEA, Table 3.3ES: Historical-Cost Net Stock of Private Fixed Assets by Industry [Billions of dollars; yearend estimates].

Wages for goods producing industries and are obtained from NIPA tables 2.2A and 2.2B: Wages and Salaries Disbursements by Industry [billions of dollars].

Employment in goods producing industries is obtained from: US Department of Labor, Bureau of Labor Statistics, series ID CES0600000001.

The money ARP is computed by dividing profits of a certain year by constant and variable capital of the preceding year. It is computed for the productive sectors. The best approximation to that are the goods producing industries. These are defined as agriculture, mining, utilities, construction and manufacturing. However, utilities are disregarded (see above). N.B. Constant capital includes only fixed and not circulating capital because of difficulties of estimating the latter on the basis of the available statistics. The inclusion of circulating capital would only depress the ARP further. See note 4 below.

Figure 6. Data from FRED, Federal Reserve Bank of St Louis.

$\mathrm{GDP}=$ real gross domestic product, BEA NIPA \$bn chained 2005 GDPC96.

Investment $=$ real private nonresidential fixed investment $\$$ bn chained 2006, PNFIC96.

Corporate profits $=$ corporate profits with IV and $\mathrm{CC}$ adjustments sa annualized CPROFIT.

Figure 7. Developed from Carchedi (2012).

Figure 8. Data from Roberts (2012b) based on IMF, BIS and authors' calculations.

Figure 9. Data for Greece from Eurostat Ameco database.

Net capital stock at 2005 prices: total economy (OKND). 
National income at current market prices (UVNN).

Price deflator gross domestic product at market prices (PVGD).

Compensation of employees: total economy (UWCD).

Figure 10. Data from UK Office of National Statistics.

Net return on capital. Quarterly rates of return of private non-financial companies $(\%)$.

Business investment. Gross fixed capital formation of private non-financial companies, quarterly £bn.

Figure 11. From Michelena (2009), chart 1, p. 90.

Figure 12. Data from Extended Penn World Tables. https://sites.google.com/a/ newschool.edu/duncan-foley-homepage/home/EPWT

$\mathrm{ARP}=\mathrm{GDP}($ column $\mathrm{X})$, employee compensation $\left(\mathrm{N}^{*} \mathrm{~W}\right)$ and capital stock $(\mathrm{K})$. $\mathrm{ARP}=\left(\mathrm{X}-\mathrm{N}^{*} \mathrm{w}\right) /(\mathrm{K}+\mathrm{N}-\mathrm{w})$.

Figures 13 and 14. Data from Extended Penn World Tables.

\section{Notes}

1. The authors support the view that the only meaningful rate of profit in Marxist terms is one based on measuring constant capital in historic costs. But there are differences among the supporters of this thesis. Kliman (2012) measures the rate of profit in historic costs and concludes that there was no significant rise in profitability during the so-called neo-liberal period. Roberts (2011), using a different measure of profit but with constant capital based on historic costs, does find such a rise. Carchedi (2011b) also finds a rise after 1986 in the average rate of profit for productive sectors. Jones (2012: 7), "using a revised measure of historic costs" also finds that there was a "recovery in the rate of profit following 1983 which was volatile, but significant."

2. For a detailed analysis of the redistribution inherent in the process of price formation, see Carchedi (1991).

3. The empirical material in this section concerns the whole of the US economy while section 2 focuses on the corporate sector and section 3 on the productive sector only (for the definition of the productive sector, see Appendix). The consideration of both only the productive sectors and also of the unproductive ones adds strength to our argument because, while the measures of the average rate of profit (ARP) and the shape of the cycle differ moderately according to whether the unproductive sectors are considered or not, the trends, the results, and the conclusions are the same.

4. All empirical research on the US rate of profit agrees with this statement. See Roberts $(2009,2011)$, Carchedi (2011a, 2011b, 2012, 2013), Kliman (2012), among others. See Roberts $(2009,2011)$ for references to other research. Basu and Manolakos (2010) applied econometric analysis to the US economy between 1948 and 2007 and found that there was a secular tendency for the rate of profit to fall with a measurable decline of about 0.3 percent a year "after controlling for countertendencies." Roberts finds an average decline of 0.4 percent a year through 2009 using the latest data.

5. The organic composition rose more in the productive sectors (see section 3 ).

6. See Carchedi (2011b) for the causes of the rise and fall of the Golden Age. See also below for a summary.

7. A similar pattern emerges in the productive sectors. Profitability peaked in 1997 (9.23 percent) and reached its lowest point in 2009 (4.45 percent). The organic composition rose from 1.75 
percent in 1977 to 2.4 percent in 2008. The rate of exploitation fell from 25.38 percent in 1997 to 16.34 percent in 2009. Profitability rose from 2002 to 2006 . So many analysts argue that the crisis cannot be due to falling profitability. Carchedi (unpublished paper) provides an exhaustive answer. Suffice it to say that the ARP rose because the rate of exploitation rose dramatically from 13.1 percent in 2003 to 40.2 percent in 2006. So the cause of the increase in the ARP was greater exploitation. A sustained recovery starts when more surplus value is produced and realized in the productive sectors rather than appropriated in distribution. There was no such recovery between 2003 and 2006, only super-exploitation. From 2006, the rate of exploitation starts falling and so does the ARP because of the rise in the organic composition (from 2.1 in 2007 to 2.9 in 2010).

8. Basu and Vasudevan (2011), like a number of other authors, argue that the "current crisis cannot be viewed as a crisis of profitability." Yet the authors also show that the cost of mechanization rose six times faster after 2000 than in the previous two decades. So the downward pressure on the rate of profit was resumed despite a rising rate of surplus value or exploitation. Therefore the authors conclude: "It was capitalism's dynamic drive to accumulate and innovate that led to the potential erosion of profitability."

9. Total US corporate profits reached a low at the end of 2008 of $\$ 971 \mathrm{bn}$ at the depth of the slump, but then recovered to surpass the previous peak and reach $\$ 1,953 \mathrm{bn}$ by the end of 2011 , but profits have declined since to $\$ 1,921$ bn by mid-2012.

10. The rate of surplus value rose from 0.47 to 0.57 , up to 2005 , or 21 percent, while the organic composition of capital rose from 1.24 to 1.31 or just 6 percent. After 2005, the organic composition began to rise sharply, while the rate of surplus value tapered off. The rate of profit fell from 2006 onwards, a good year or more before the credit crunch and two years before the recession.

11. Minqi Li (2008).

12. Roberts (2012).

13. Smith (2010).

14. Following Marx, by destruction of capital, we mean essentially bankruptcies of firms and unemployment.

15. Kalecki (1942).

16. The measure for the US rate of profit in Figure 2 is based on the "whole economy" and not just the corporate sectors as in Figure 5. So the figures are based on different categories for the measurement of profit and fixed assets as a result. Figure 2 also starts in 1982, while Figure 5 starts in 1947. So the turning points in profitability differ slightly. Nevertheless, the same trends appear in both measures.

17. See Mitchell (1927), Tinbergen (1939), Haberler (1960), Feldstein and Summers (1997), Bakir and Campbell (2006), Camara (2010). More recently, Tapia Granados (2012), using regression analysis, finds that, over 251 quarters of US economic activity from 1947, profits started declining long before investment did and that pre-tax profits can explain 44 percent of all movement in investment, while there is no evidence that investment can explain any movement in profits. Yet the Keynesians ignore this evidence and continue with the mantra that "it is investment that calls the tune," to use the phrase of Hyman Minsky.

18. We disregard military Keynesianism.

19. This, by the way, undermines conventional economics at its very foundations because it shows the fallacy of equilibrium: demand and supply do not tend towards a price at which they meet. But even if they did meet, the fall in the ARP would upset that equilibrium and even if it were restored, it would be so at a constantly decreasing level of profitability. So there would be a tendency towards crises even if demand and supply met at each point.

20. This is a simplification. The state appropriates surplus value by e.g. taxing both sectors. The point is that sector I receives more surplus value to invest than that it loses to the state.

21. See Carchedi (2012).

22. See Roberts (2012).

23. There is no affinity between this conclusion and that of the Austrian school. For the Austrian school the economy, if not tampered with, tends towards equilibrium (rather than towards crises, 
as in Marx) and government intervention is the cause of crises (rather than being one of the many countertendencies).

24. See Carchedi (2011b). See also the IMF World Economic Outlook of October 2012, chapter 3, on the reasons for the reduction in US federal debt after 1945. According to the IMF case study, high fiscal surpluses, strong GDP growth and inflation accompanied the reduction in the debt ratio, not Keynesian cuts in interest rates or increased budget deficits (although the IMF tries to suggest the former as the cause).

25. Carchedi (2013).

26. We are not arguing here whether Italy or the other weaker countries should retain or leave the euro. Rather, the purpose is to clarify the real advantages/disadvantages of reverting to competitive devaluation.

27. Stiglitz (2002).

28. Bourne comments in an article for City AM that "Estonia proves that a turnaround through swift, sharp austerity is possible for a country provided it has stable pre-existing conditions, or is willing to undertake radical supply-side reform alongside curbing spending. It's these conditions that are wrong in southern European countries, which have excessive borrowing, unsustainable welfare states, high debt burdens, unreformed and illiberal labour markets, excessive and burdensome regulation and dysfunctional banking sectors. Reform on these fronts is just as important as reining in spending." http://www.cityam.com/article/estonia-proves-it-s-possible-cut-spending-and-continue-grow

29. In 2010, Krugman seemed to recognize that there could be "debt-driven slumps." He wrote a piece with Gauti Eggertsson (2010) that argued an "overhang of debt on the part of some agents who are forced into deleveraging is depressing demand." Yet more recently, Krugman appeared to deny the role of public sector debt in crises. Krugman says it does not matter in a "closed economy," i.e. one where one man's debt is another's asset. It's only a problem if you owe it to foreigners. http://krugman.blogs.nytimes.com/2011/12/28/debt-is-mostly-money-we-owe-to-ourselves/

30. Manzanelli $(2010: 30,36,48)$ seems to ascribe the rise in the ARP in the post-convertibility period basically (but not exclusively) to the neo-liberal massive transfer of value from labor to capital. But his data can be used to support Marx's thesis that the movement of the ARP (and thus of the economic cycle) is basically determined by the movement of the organic composition of capital. Lower labor costs and higher exploitation weaken the tendential fall.

31. A particularly important reaction to the crisis was the occupation of factories by the Argentinean workers. Between 160 and 180 factories had been occupied in 2004, employing about 10,000 workers (Atzeni and Ghigliani 2007). There is no room here to deal adequately with this question. See Ghigliani $(2002,2003)$.

32. Manzanelli (2012, chart 3), argues that the ARP falls tendentially since 1993 and that it rises up to 2010. It seems that for Michelena the long-term slump ended around 1985 and that the 1998-2002 crisis is a short, downwards period within a longer upwards cycle. These are important points that, however, can be overlooked because the question here is whether the Argentinean economy exited the slump due to devaluation and pro-labor redistribution or not and what lesson can be drawn for the weaker euro countries.

33. Nevertheless, to this day, Argentina has been cut off from international lending. At present, it is likely that Argentina will have to default again, on bonds issued in the debt restructuring of 2005 and 2010 (Webber 2012).

34. Writing from a capitalist perspective, Domingo Cavallo (2011), the former Argentine finance minister, pointed out that the improvement in the trade balance was "a piece of luck," due to the greatly increased price of soya, and not the result of competitive devaluation. While skyrocketing export prices have certainly improved the balance of trade, the basic reasons for the recovery are those outlined below.

35. But began falling again to 20.6 percent in 2009 , in the onset of the new global crisis.

36. But after that year it started declining. It fell by 1.9 percentage points from 2007 to 2008 and by a further 5.9 percentage points from 2008 to 2009. After the 2001 default, imports controls and 
currency restrictions have been imposed, the government has tapped central bank reserves to pay its debt obligations, and inflation has been running at about 25 percent. These are indicators that the economy is running out of steam.

\section{References}

Atzeni, M., and P. Ghigliani (2006-07) “Argentina: come viene organizzata la produzione e come vengono prese le decisioni nelle fabbriche autogestite dai lavoratori?" Proteo, no. 3 (2006), no. 1 (2007), Rome.

Bakir, E., and A. Campbell (2006) "The Effect of Neoliberalism on the Fall of the Rate of Profit in Business Cycles," Review of Radical Political Economics, vol. 38, no. 3.

Basu, D., and P. Manolakos (2010) Is There a Tendency for the Rate of Profit to Fall? Econometric Evidence for the U.S. Economy, 1948-2007. University of Massachusetts, Amherst.

Basu, D., and R. Vasudevan (2011) Technology, Distribution and the Rate of Profit in the US Economy: Understanding the Current Crisis. University of Massachusetts, Amherst.

Bourne, R. (2012) Estonia: A Case Study: How and Why Estonia Embraced Austerity. http://www. cps.org.uk

Carchedi, G. (1991) Frontiers of Political Economy. London: Verso.

- (2011a) Behind the Crisis. Leiden: Brill.

— (2011b) "Behind and Beyond the Crisis," International Socialism, no. 132. http://gesd.free.fr/ carchedi11.pdf

_ (2012) “Could Keynes End the Slump? Introducing the Marxist Multiplier," International Socialism, no. 136. http://www.isj.org.uk/index.php4?id=849\&issue $=136$

_ (2013) "From the Crisis of Surplus Value to the Crisis of the Euro," World Review of Political Economy, vol. 3, no. 3: 288-312.

- (unpublished paper) "Marx's Law and the Crisis: An Empirical Study."

Cavallo, D. (2011) "Looking at Greece in the Argentinean Mirror," July 15. http://voxeu.org/index. php?q=node $/ 6758$

Feldstein, M., and L. Summers (1977) Is the Rate of Profit Falling? http://www.brookings.edu/ /media/... feldstein_summers_wachter.PDF

Ghigliani, P. (2002) “Crisi nella periferia e movimento dei lavoratori: il collasso argentino," Proteo, no. 1.

— (2003) "Nuovo movimento operaio e l'occupazione delle fabbriche in Argentina," Proteo, no. 1.

Haberler, G. (1960) Prosperity and Depression: A Theoretical Analysis of Cyclical Movements. League of Nations, 1941.

IMF (2012) World Economic Outlook, October. http://www.imf.org/external/pubs/ft/weo/2012/02/index. htm

Jones, P. (2012) "Depreciation, Devaluation and the Rate of Profit," paper to the WAPE/AHE/IIPPE conference.

Kalecki, M. (1942) A Theory of Profits. http://gesd.free.fr/kalecki42

Kliman, A. (2012) The Failure of Capitalist Production. London: Pluto Press.

Krugman, P., and G. Eggertsson (2010) Debt, Deleveraging and the Liquidity Trap, mimeo. Federal Reserve Bank of New York.

Manzanelli, P. (2010) "Evolución y dinámica de la tasa general de ganancia en la Argentina reciente," Realidad Ecónomica, no. 256: 29-61.

_ (2012) "La tasa de ganancia durante la posconvertibilitad. Un balance preliminar," Apuntes para el cambio, year 2, no. 3: 5-17.

Minqi, L. (2008) The Rise of China and the Demise of the Capitalist World Economy, 4th ed. Cambridge: Harvard University Press.

Minqi, L., F. Xiao, and A. Zhu (2007) "Long Waves, Institutional Changes and Historical Trends," Journal of World-Systems Research, vol. XIII, no. 1. 
Michelena, G. (2009) "La evolucion de la tasa de Ganancia en la Argentina (1960-2007): caida e recuperación," Realidad economica, no. 208: 83-106.

Mitchell, W. C. (1927) Business Cycles: The Problem and its Setting. New York: National Bureau of Economic Research.

Roberts, M. (2009) The Great Recession: Profit Cycles, Economic Crisis-A Marxist View. Lulu.com

_ (2010) "The Causes of the Great Recession: Mainstream and Heterodox Interpretations and the Cherry Pickers," paper at the 10th conference of the Association of Heterodox Economists.

(2011) "Measuring the Rate of Profit, Profit Cycles and the Next Recession," paper to the 11th AHE Conference.

- (2012a) http://thenextrecession.wordpress.com/2012/05/27/krugman-and-depression-economics - (2012b) "A World Rate of Profit," paper to the WAPE/AHE/IIPPE conference.

Smith, J. (2010) "Imperialism and the Globalisation of Production," $\mathrm{PhD}$ thesis, University of Sheffield, July.

Stiglitz, J. (2002) “Is Keynesian Economics Dead?” http://www.project-syndicate.org/commentary/ is-keynesian-economics-dead, May 7.

Tapia Granados, J. (2012) Does Investment Call the Tune? Empirical Evidence and Endogenous Theories of the Business Cycle. http://sitemaker.umich.edu/tapia_granados/files/does_investment_call_the_ tune_may_2012_forthcoming_rpe_pdf

Tinbergen, J. (1939) Statistical Testing of Business-Cycle Theories, Volume II: Business Cycles in the United States of America 1919-1932. Geneva: League of Nations.

Tognonato, C. (2005) "Le fabbriche agli operai," Il Manifesto, February 1.

Webber, J. (2012) “'Reckless' Argentina risks threat to growth,” Financial Times, November 23. http:// www.ft.com/intl/cms/s/0/2d6097a8-34b5-11e2-8986-00144feabdc0.html\#axzz2DeOiRHcU 